\title{
FARM MECHANIZATION LEADING TO MORE EFFECTIVE ENERGY- UTILIZATION FOR CASSAVA AND YAM CULTIVATION IN RIVERS STATE, NIGERIA
}

\author{
S.O. Nkakini ${ }^{a}$, M.J. Ayotamuno ${ }^{a}$, S.O.T. Ogajii ${ }^{b+}$, S.D. Probert ${ }^{b}$ \\ ${ }^{a}$ Agricultural \& Environmental Engineering Department, Rivers State University of Science \& \\ Technology, Port Harcourt. P.M.B. 5080, Rivers State, Nigeria \\ ${ }^{\mathrm{b}}$ School Of Engineering, Cranfield University, Bedfordshire. United Kingdom. MK43 OAL \\ ${ }^{+}$Corresponding author
}

\begin{abstract}
Surveys have been conducted, under the auspices of the Ministry of Agriculture and Agricultural Development Projects (ADPs), in the 23 local-government areas of the Rivers State, Nigeria. A structured questionnaire, personal visits to farms and interactions with information repositories were used. The quantities of energy consumed by tractors used in activities associated with the growing of cassava and yam crops in those areas were compared with traditional operations, using just manual labour. Within the period of $1986 \rightarrow 2004$, the total energy utilizations in the production of these crops, in the 23 local government areas, were $2738.87 \mathrm{MJ}$ and $33.5 \mathrm{MJ}$ for traditional manual and tractor power operations respectively. The tractorization intensity (TI) dropped from $0.352 \mathrm{hp} / \mathrm{ha}$ in 1986 to $0.345 \mathrm{hp} / \mathrm{ha}$ in 2004 . This result was below the presently advocated $0.5 \mathrm{hp} / \mathrm{ha}$ for agricultural operations in order to increase crops production. This study identified the causes of this shortfall and recommended, at least for the short-term future, that farm industrialization of all sectors should be subsidized.
\end{abstract}

Keywords: farm mechanization, energy utilization, Rivers State.

\section{Nomenclature / Abbreviations}

$\mathrm{A}_{\mathrm{c}}$

ADP

FCMS

FGOMS

$\mathrm{h}$

h $\bar{P}$

IOMS

$\mathrm{m}$

$\mathrm{N}$

$\mathrm{n}$

$\mathrm{P}_{\mathrm{u}}$

SGOMS

TI
Total land-area subjected to mechanization

Agricultural Development Project

Farmers' Cooperative Management System

Federal-Government Owned Management-System

Weighted average size of tractors

Average tractor power

Individual Owned Management System

4 group of tractors with respect to capacity

Number of tractors available

Number of tractors in a capacity range

Total tractor power in use

State-Government Owned Management-System

Tractorization intensity 


$\begin{array}{ll}\% 0 \mathrm{p} & \text { Percentage of operational tractors } \\ \sum & \text { Summation }\end{array}$

\section{HISTORIC PERSPECTIVE}

In the pre-independence era of Nigeria, the dominant role of agriculture in the nation's economy was taken for granted. The first decade, after the country's independence, was a period during which Regional Governments became involved directly in agricultural production in order to enhance the output of the private sector, peasant farmers and fishermen [1]. During this period, the main agricultural productions were mainly for export crops, e.g. cocoa in the Western Region, groundnuts and cotton in the Northern Region, as well as palm produce and rubber in the Eastern Region. Also national selfsufficiency in food production did not pose any problems worthy of public attention. However, after two decades of independence, despite the greater involvement of the Government, there was a rapid deterioration in the national and Rivers State's agricultural situation. Food shortages worsened as a result of the "Oil Boom" which led to the migration of labour from the agricultural sector. Before 1971, Rivers State practised both subsistence and cash-crop agriculture and relied solely on human beings as the source of power. Among the major crops grown were rubber, oil palm, cassava, yam, cocoyam and pepper. However, their productivities were low, because, as Liljedahl et al [2] stated, human beings are limited to less than $0.1 \mathrm{~kW}$ continuous power output. To overcome this limitation, the introduction of agricultural mechanization in the State started during the period of the first military administration (1967-1976) with the procurement of the first batch of tractors and associated farm implements in 1971. The State established several farms and tractor-hiring programmes, as well as trained the requisite manpower at the Agricultural Mechanization Training Centre in Oyo State in 1971 to handle the machinery fleet. Thereafter, successive military and civilian government administrations procured various tractors as the need arose.

In Rivers State, the farm holdings are small, ranging from 0.25 to 5 ha. They are owned and operated by farmers and their households but often widely dispersed spatially $[3,4]$. Each farmer and his household cultivated between 2 and 4 non-contiguous plots in a farming season. During this period under review in Rivers State, the land-preparation operations, namely tillage and cultivation, break and stir up the soil in readiness for crop planting [5] were predominantly manual operation actions using universally accepted implements.

According to Kepner et al [6], the increased production that has been achieved during the past century resulted from the growing of better crop varieties, the more effective use of fertilizers, improved cultural practices, and, more importantly, the increased utilization of (i) more appropriate non-human energy and (ii) employing functionally-appropriate machines and implements.

Thus, the objective of this investigation was to collate information on the present acceptances of farm mechanization energy-utilization and TI in the Rivers State. This 
knowledge it is hoped will assist the government in encouraging Nigerian farmers to adopt the more profitable utilization of machine power.

\section{THE INFORMATION}

The main sources of evidence for this investigation were obtained from the State Ministry of Agriculture, through personal visits to the farms and discussions with record holders. Field surveys were conducted in the 23 local-government areas of the State. Further data were obtained from answers to a structured questionnaire concerning agricultural mechanization procedures; farm sizes, cultivation practices; use of tractors and implements; labour utilization and requirements; energy utilization; timeliness of agricultural operations, availability of credit facilities; farmers' social conditions, such as education, knowledge of farm machines; availability of repair facilities; as well as make, model, number, capacity and year of purchase of each tractor.

\section{DATA COLLECTION AND PROCESSING}

Information collected for each of the 23 local-government areas, using both primary and secondary sources, have been analysed. The primary data were obtained from the structured questionnaire, personal contact and oral interviews. Some physical inspections were also undertaken. By a secondary method, relevant information was obtained from agricultural documents (such as bulletins), workshops and seminars.

The assessment of the degree of mechanization achieved was accomplished in two ways. The first was the method whereby the current tractorization intensity (TI) in hp/ha units in the State was computed using the definition proposed by Anazodo et al. [7], viz:

$$
\mathrm{TI} \quad=\frac{\mathrm{P}_{\mathrm{U}}}{\mathrm{A}_{\mathrm{C}}}
$$

The second assessment was based on an energy analysis. Suitable energy equivalents for human and tractor powers were used to convert the man-hr and tractor-hr expenditures into $\mathrm{MJ}$ of energy consumed [8] as $\mathrm{kWh}=3.600 \times 10^{6} \mathrm{~J}$ and $0.5 \mathrm{hp} / \mathrm{ha}=0.373 \mathrm{~kW} / \mathrm{ha}$.

For the important crops grown in Rivers State, the energy utilized in the various operations namely land-clearing, ridging, mound making, planting, weeding and harvesting were analysed from the gathered information.

\section{DISCUSSION}

An appraisal of tractor acquisitions $(1971 \rightarrow 2004)$ revealed those that were available for farming in Rivers State are shown in Table I: 17 different designs of tractors were used in the State. Table 2 shows the percentage distribution of purchases according to models: a total of 10 different tractor makes were used. 
In Table 3, tractor procurement, by the State government, has been grouped into three decades, $1971 \rightarrow 1980,1981 \rightarrow 1990$, and $1991 \rightarrow 2000$ as the first, second and third decades respectively because ten-year service life was expected of each tractor [9]. Overall, FIAT tractors were the most common in Rivers State, Nigeria.

The appalling statistic revealed in Table 4, concerning actual tractor availability, could be attributed to the poor maintenance-programmes and repair facilities with respect to farming Nigeria.

\section{TILLAGE AND CULTIVATION}

Table 5, compares the field operation rates by farmers in Rivers State using either (i) hand-tools or (ii) machine power. The total of mean manual and machine indicated field works of 317.0 man-days/ha and 1.04 machine-days/ha, respectively, to achieve the same task, are shown. An analysis indicated that 32.6 man-days/ha of manual labour were used for land preparation to achieve the same as 0.10 machine days/ha when machine power was employed. The ridging and cassava planting field work utilized 0.24 machine-days/ha or 43.8 man-days/ha. Mound making and yam planting used 57.8 mandays/ha or 0.18 machine-days/ha to achieve the same end. The field work which involved, first, general weeding used 40.0 man-days/ha or 0.14 machine-days/ha. After which root weeding consumed 36.7 man-days/ha or 0.12 machine-days/ha. Manual field work is time-consuming and requires a large amount of human labour. This situation widespread amongst Rivers State farmers, who were predominantly hand-tool farmers.

\section{ENERGY UTILIZATION IN HUMAN AND MACHINE POWERED AGRICULTURAL TECHNOLOGIES}

Most traditional technologies practised in Rivers State are highly ineffective. From Table 5 , it is clear that for the same cassava production per hectare, a total of $1468 \mathrm{MJ}$ and 18 MJ of energy was expended for manual and machine power, respectively. The production of yam per hectare utilized a total of about $1524 \mathrm{MJ}$ and $18 \mathrm{MJ}$ for manual and machine power, respectively. This makes an overwhelming case for the use of tractors, in these agricultural operations.

Figures 1 and 2, showed that overall manual labour energy utilization for the same endproduct was approximately 83 times the energy required when using the tractor. Energy utilization for tillage and cultivation operations in regards to land preparation, weeding and harvesting was far greater when supplied by manual labour rather than by machine.

Stout et al [10], reported specific human energy consumption for bush clearing as $1680 \mathrm{MJ}$, and 19.4 man-days were required to prepare a hectare of land, whereas for the same task, the machine required as $0.88 \mathrm{MJ}$ energy utilization and 0.019 machine-days per hectare. 
Energy utilization for manual weeding was $1320 \mathrm{MJ}$ and $2.29 \mathrm{MJ}$ for machine field operation: 32.6 man-day/ha and 0.015 MJ machine effort were reported [10]. Energyrelated data from a number of tropical cultivation systems and products for which cassava was one of them have been averaged by Leach [11] as $0.749 \mathrm{MJ}$ for manual labour and $0.0487 \mathrm{MJ}$ when using machine power.

\section{CONCLUSIONS}

Farmers in the Rivers State employed only a low level of mechanization. The resulting low productivities were due to: poverty; ignorance; lack of incentive to use of machinery in agricultural practices; and traditional tools being cheap, simple and readily available to the poor farmer. However, the latter was very time consuming. The total energy utilizations for the manual and machine operations per hectare for achieving the same outcome were $2738.9 \mathrm{MJ}$ and $33.5 \mathrm{MJ}$. The human energy utilization was so much for manual methods that farmers are reduced to subsistence levels. The cultivations of yam and cassava crops require more energy expenditure per hectare of land for manual than mechanical operations in Nigeria.

Tractorization intensity (T.I) decreased from $0.352 \mathrm{hp} / \mathrm{ha}$ in 1986 to $0.345 \mathrm{hp} / \mathrm{ha}$ in 2004 because agricultural activities in Rivers State were in decline. The $0.345 \mathrm{hp} / \mathrm{ha}$ tractorpower utilization remained far below the $0.5 \mathrm{hp} / \mathrm{ha}$, as recommended for effective agriculture operations [12]. Hence the much needed food self-sufficiency has continued to elude the State. A similar conclusion applies for the entire country. Planting and harvesting of all the major crops need to be mechanized and more land used for agriculture.

A concerted effort towards achieving standardization of the components for tractors suited for the peculiar agro-physical and climatic conditions is needed in Nigeria, as this would ensure that tractors are more likely to function well throughout their service lives.

Government encouragement and incentives for farmers to use farm machinery is a desirable challenge.

TABLE 1: TRACTORS PURCHASED BY THE RIVERS STATE GOVERNMENT $(1971 \rightarrow$ 2004)

\begin{tabular}{|c|c|c|c|c|c|}
\hline YEAR & $\begin{array}{l}\text { TRACTOR } \\
\text { MANUFACTURER }\end{array}$ & MODEL & $\begin{array}{l}\text { POWER } \\
(\mathrm{kW})\end{array}$ & QUANTITY & $\begin{array}{lr}\text { TOTAL } & \text { NUMBER } \\
\text { OF } & \text { TRACTORS } \\
\text { PURCHASED } & \text { IN } \\
\text { THE } & \text { SPECIFIED } \\
\text { YEAR } & \end{array}$ \\
\hline 1971 & $\begin{array}{l}\text { MASSEY FERGUSON } \\
\text { MASSEY FERGUSON } \\
\text { FORD }\end{array}$ & $\begin{array}{l}135 \\
165 \\
5000(\mathrm{D})\end{array}$ & $\begin{array}{l}48 \\
60 \\
48\end{array}$ & $\begin{array}{r}20 \\
3 \\
2\end{array}$ & 25 \\
\hline 1972 & MASSEY FERGUSON & 165 & 60 & 8 & 8 \\
\hline 1976 & $\begin{array}{l}\text { JOHN DEERE } \\
\text { DAVID BROWN }\end{array}$ & $\begin{array}{l}- \\
1990\end{array}$ & $\begin{array}{l}60 \\
53\end{array}$ & $\begin{array}{r}12 \\
7\end{array}$ & 19 \\
\hline
\end{tabular}




\begin{tabular}{|c|c|c|c|c|c|}
\hline 1977 & DAVID BROWN & 1990 & 60 & 3 & 3 \\
\hline 1978 & $\begin{array}{l}\text { FIAT } \\
\text { FIAT }\end{array}$ & $\begin{array}{l}80 \text { (DT) } \\
640 \text { (DT) }\end{array}$ & 82 & $\begin{array}{l}10 \\
15\end{array}$ & 25 \\
\hline 1984 & $\begin{array}{l}\text { STEYR } \\
\text { STEYR }\end{array}$ & $\begin{array}{l}8120 \mathrm{~A} \\
8080 \mathrm{~A}\end{array}$ & $\begin{array}{l}80 \\
52\end{array}$ & $\begin{array}{r}3 \\
10\end{array}$ & 13 \\
\hline 1985 & $\begin{array}{l}\text { STEYR } \\
\text { STEYR }\end{array}$ & $\begin{array}{l}\text { FIAT } 666 \\
768\end{array}$ & $\begin{array}{l}52 \\
52\end{array}$ & $\begin{array}{r}5 \\
15\end{array}$ & 20 \\
\hline 1986 & $\begin{array}{l}\text { STEYR } \\
\text { STEYR } \\
\text { STEYR } \\
\text { MARSHAL / LEYLAND } \\
\text { MARSHAL / LEYLAND } \\
\text { MARSHAL / LEYLAND }\end{array}$ & $\begin{array}{l}768 \\
8130 \\
8075 \\
- \\
- \\
-\end{array}$ & $\begin{array}{l}97 \\
52 \\
52 \\
52 \\
52 \\
60\end{array}$ & $\begin{array}{l}5 \\
9 \\
9 \\
7 \\
3 \\
8\end{array}$ & 41 \\
\hline 1989 & $\begin{array}{l}\text { STEYR } \\
\end{array}$ & 8075 & 52 & 50 & 50 \\
\hline 1990 & BELORUS & - & 60 & 50 & 50 \\
\hline 1992 & ZETOR & 7745 & 60 & 21 & 21 \\
\hline 1996 & FIAT & 8066 (DT) & 60 & 20 & 20 \\
\hline 1997 & $\begin{array}{l}\text { FIAT } \\
\text { FIAT }\end{array}$ & $\begin{array}{l}8066 \\
70.56\end{array}$ & $\begin{array}{l}52 \\
52\end{array}$ & $\begin{array}{l}14 \\
10\end{array}$ & 24 \\
\hline 2001 & FIAT & 70.56 & 52 & 3 & 3 \\
\hline 2002 & NEW HOLLAND & 70.56 & 52 & 10 & 10 \\
\hline 2003 & - & - & - & - & - \\
\hline 2004 & - & - & - & - & - \\
\hline & & & & TOTAL & 332 \\
\hline
\end{tabular}

TABLE 2: NUMBER OF TRACTORS (ACCORDING TO MANUFACTURER) PURCHASED BY RIVERS RIVERS STATE GOVERNMENT IN THE PERIOD $1971 \rightarrow 2004$

\begin{tabular}{|l|r|r|}
\hline TRACTOR MANUFACTURER & \multicolumn{1}{|l|}{ NUMBER } & \% OF TOTAL \\
\hline MASSEY FERGUSON & 31 & 9.32 \\
\hline FORD & 2 & 0.60 \\
\hline JOHN DEERE & 2 & 3.61 \\
\hline DAVID BROWN & 10 & 3.10 \\
\hline FIAT & 77 & 23.18 \\
\hline STEYR & 101 & 30.40 \\
\hline MARSHALL / LEYLAND & 18 & 5.41 \\
\hline BELORUS & 50 & 15.05 \\
\hline ZETOR & 21 & 6.32 \\
\hline FIAT / NEW HOLLAND & 10 & 3.01 \\
\hline TOTAL & $\mathbf{3 3 2}$ & $\mathbf{1 0 0}$ \\
\hline
\end{tabular}


TABLE 3: TRACTORS PURCHASED BY THE RIVERS STATE GOVERNMENT WITHIN SPECIFIED PERIODS

\begin{tabular}{|c|c|c|c|}
\hline YEARS & TRACTOR MAKE & NUMBER & $\begin{array}{l}\text { PERCENTAGE OF TOTAL } \\
\text { NUMBER } \\
\text { PURCHASED } \\
\text { WITHIN } \\
(\%)\end{array}$ \\
\hline $1971 \rightarrow 1980$ & $\begin{array}{l}\text { MASSEY FERGUSON } \\
\text { FORD } \\
\text { JOHN DEERE } \\
\text { DAVID BROWN } \\
\text { FIAT }\end{array}$ & $\begin{array}{r}31 \\
2 \\
12 \\
10 \\
25\end{array}$ & $\begin{array}{r}38.75 \\
2.50 \\
15.00 \\
31.25 \\
12.50\end{array}$ \\
\hline SUB TOTAL FC & ${ }^{\mathrm{ST}}$ DECADE & 80 & 100 \\
\hline $1981 \longrightarrow 1990$ & $\begin{array}{l}\text { STEYR } \\
\text { MARSHAL / LEYLAND } \\
\text { FIAT } \\
\text { BELORUS }\end{array}$ & $\begin{array}{r}101 \\
18 \\
5 \\
50\end{array}$ & $\begin{array}{r}58.05 \\
10.34 \\
2.87 \\
28.74\end{array}$ \\
\hline SUB TOTAL FC & ${ }^{\mathrm{ND}} \mathrm{DECADE}$ & 174 & 100 \\
\hline $1991 \longrightarrow 2000$ & $\begin{array}{l}\text { ZETOR } \\
\text { FIAT }\end{array}$ & $\begin{array}{l}21 \\
44\end{array}$ & $\begin{array}{l}32.30 \\
67.70\end{array}$ \\
\hline SUB TOTAL FC & ${ }^{\mathrm{RD}} \mathrm{DECADE}$ & 65 & 100 \\
\hline $2001 \rightarrow 2004$ & $\begin{array}{l}\text { FIAT } \\
\text { NEW HOLLAND }\end{array}$ & $\begin{array}{r}3 \\
10\end{array}$ & $\begin{array}{l}23.08 \\
76.92\end{array}$ \\
\hline \multicolumn{2}{|c|}{ SUB TOTAL FOR YEARS 2001 - 2004} & 13 & 100 \\
\hline \multicolumn{2}{|c|}{ GRAND TOTAL } & 332 & \\
\hline
\end{tabular}

\section{TABLE 4: SOME FARMS IN RIVERS STATE AND THEIR LEVELS OF INVOLVEMENT IN MECHANIZATION}

\begin{tabular}{|c|c|c|c|c|c|c|}
\hline Name of Farm & $\begin{array}{l}\text { Type of } \\
\text { management } \\
\text { system }\end{array}$ & $\begin{array}{l}\text { Size of farm } \\
\text { (Hectares) }\end{array}$ & $\begin{array}{l}\text { Number } \\
\text { of } \\
\text { tractors } \\
\text { available }\end{array}$ & $\begin{array}{l}\text { Staff } \\
\text { Strength }\end{array}$ & $\begin{array}{l}\text { Number of } \\
\text { Tractors } \\
\text { in } \\
\text { operational } \\
\text { condition } \\
\end{array}$ & $\begin{array}{l}\text { Number of } \\
\text { Tractors in } \\
\text { day-to-day } \\
\text { use }\end{array}$ \\
\hline $\begin{array}{l}\text { School-to-land Authority Farm, } \\
\text { Iriebe, Obio/Akpor L.G.A. }\end{array}$ & SGOMS & 150 & 6 & $>25$ & 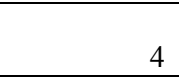 & 1 \\
\hline $\begin{array}{l}\text { Agricultural Development } \\
\text { Programme Farm, Okoro-Odo, } \\
\text { Obio/Akpor L.G.A. }\end{array}$ & SGOMS & 100 & 4 & $>25$ & 2 & 1 \\
\hline $\begin{array}{l}\text { Nigeria Prosins Farm, Eleme, } \\
\text { Ikwerre L.G.A. }\end{array}$ & FGOMS & 80 & 4 & $>25$ & 1 & 1 \\
\hline $\begin{array}{l}\text { Zuru Farm, Rumuigbo, } \\
\text { Odo, Obio/Akpor L.G.A. }\end{array}$ & IOMS & 20 & - & $<10$ & - & - \\
\hline $\begin{array}{l}\text { Joel Nwala Farm, Omuma, } \\
\text { Omuma L.G.A. }\end{array}$ & IOMS & 30 & - & $<10$ & - & - \\
\hline $\begin{array}{l}\text { Chief N. U. Njoku Farm, Etch, } \\
\text { Etche L.G.A. }\end{array}$ & IOMS & 30 & - & $<20$ & - & - \\
\hline $\begin{array}{l}\text { Bionu Bangha Farmers, } \\
\text { Cooperative Society Ltd. Bionu } \\
\text { Bangha, Khana L.G.A. }\end{array}$ & FCMS & 90 & - & $<10$ & - & - \\
\hline
\end{tabular}




\begin{tabular}{|c|c|c|c|c|c|c|}
\hline $\begin{array}{l}\text { Amadi Electrical / Farms, } \\
\text { Igwurata, Ikwerre L.G.A. }\end{array}$ & IOMS & 20 & - & $<10$ & - & - \\
\hline $\begin{array}{l}\text { Antali Farm Atali } \\
\text { Obio/Akpor L.G.A. }\end{array}$ & SGOMS & 100 & 2 & $>25$ & 1 & 1 \\
\hline $\begin{array}{l}\text { Rupheiza Farms, Atali, } \\
\text { Obio/Akpor L.G.A. }\end{array}$ & IOMS & 15 & - & $<10$ & - & - \\
\hline $\begin{array}{l}\text { Areta Farm, Atali, } \\
\text { Odo, Obio/Akpor L.G.A. }\end{array}$ & IOMS & 20 & - & $<10$ & - & - \\
\hline Total & & 655 & 16 & - & 8 & 4 \\
\hline
\end{tabular}

TABLE 5: COMPARISON OF THE FIELD-OPERATION RATES AND MANUAL ENERGY UTILIZATUION WITH THE MECHANIZED ALTERNATIVES IN RIVERS STATE

\begin{tabular}{|c|c|c|c|c|c|}
\hline \multirow[t]{2}{*}{$\begin{array}{l}\text { Field } \\
\text { operations }\end{array}$} & \multirow{2}{*}{$\begin{array}{l}\text { Mean manual } \\
\text { field-work rate } \\
\text { (man days / ha) }\end{array}$} & \multirow{2}{*}{$\begin{array}{l}\text { Mean machine } \\
\text { field-work rate } \\
\text { (machine- } \\
\text { days/ha) for } \\
\text { achieving the } \\
\text { same previous } \\
\text { section }\end{array}$} & \multirow[t]{2}{*}{ Crop } & \multicolumn{2}{|c|}{$\begin{array}{c}\text { Total energy used } \\
\text { per ha }\end{array}$} \\
\hline & & & & $\begin{array}{l}\text { Manual } \\
(\mathrm{MJ})\end{array}$ & $\begin{array}{l}\text { Machine } \\
\text { (MJ) }\end{array}$ \\
\hline Land clearing & 32.6 & 0.10 & Yam / Cassava & 281.66 & 3.22 \\
\hline $\begin{array}{ll}\text { Ridging } & \text { for } \\
\text { cassava } & \\
\text { planting } & \end{array}$ & 43.8 & 0.15 & Cassava & 378.43 & 4.83 \\
\hline $\begin{array}{l}\text { Mound making } \\
\text { for yams }\end{array}$ & 57.8 & 0.18 & Yam & 499.39 & 5.80 \\
\hline $\begin{array}{l}\text { Cassava } \\
\text { planting }\end{array}$ & 57.8 & 0.18 & Cassava & 244.51 & 2.90 \\
\hline Yam planting & 17.3 & 0.06 & Yam & 149.47 & 1.93 \\
\hline $\begin{array}{l}\text { Weeding } \\
\text { (root crops) }\end{array}$ & 36.7 & 0.12 & Yam / Cassava & 317.09 & 3.87 \\
\hline $\begin{array}{l}\text { Weeding } \\
\text { (General) }\end{array}$ & 40.0 & 0.14 & - & 345.60 & 4.51 \\
\hline $\begin{array}{l}\text { Cassava } \\
\text { harvesting }\end{array}$ & 28.5 & 0.09 & Cassava & 246.24 & 2.90 \\
\hline Yam harvesting & 32.0 & 0.11 & Yam & 276.48 & 3.54 \\
\hline Total & 346.5 & 1.14 & & 2738.87 & 33.50 \\
\hline
\end{tabular}




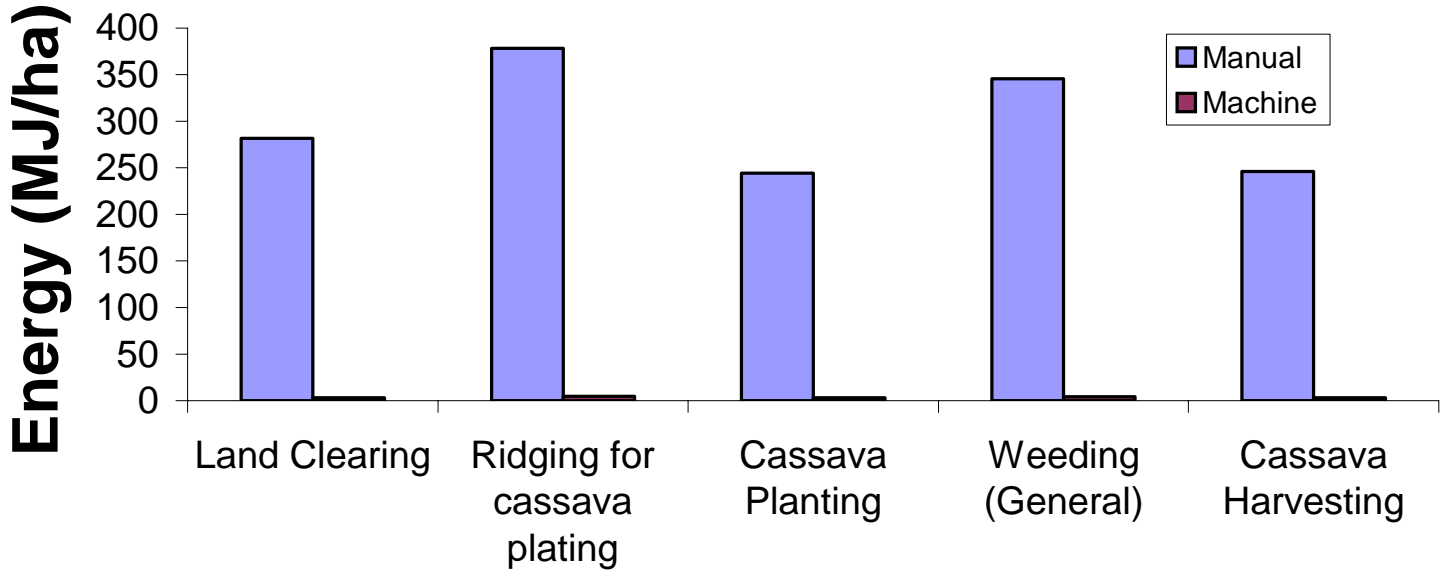

\section{Field Operation}

Fig.1: Energy utilization in cassava cultivation in Rivers State.

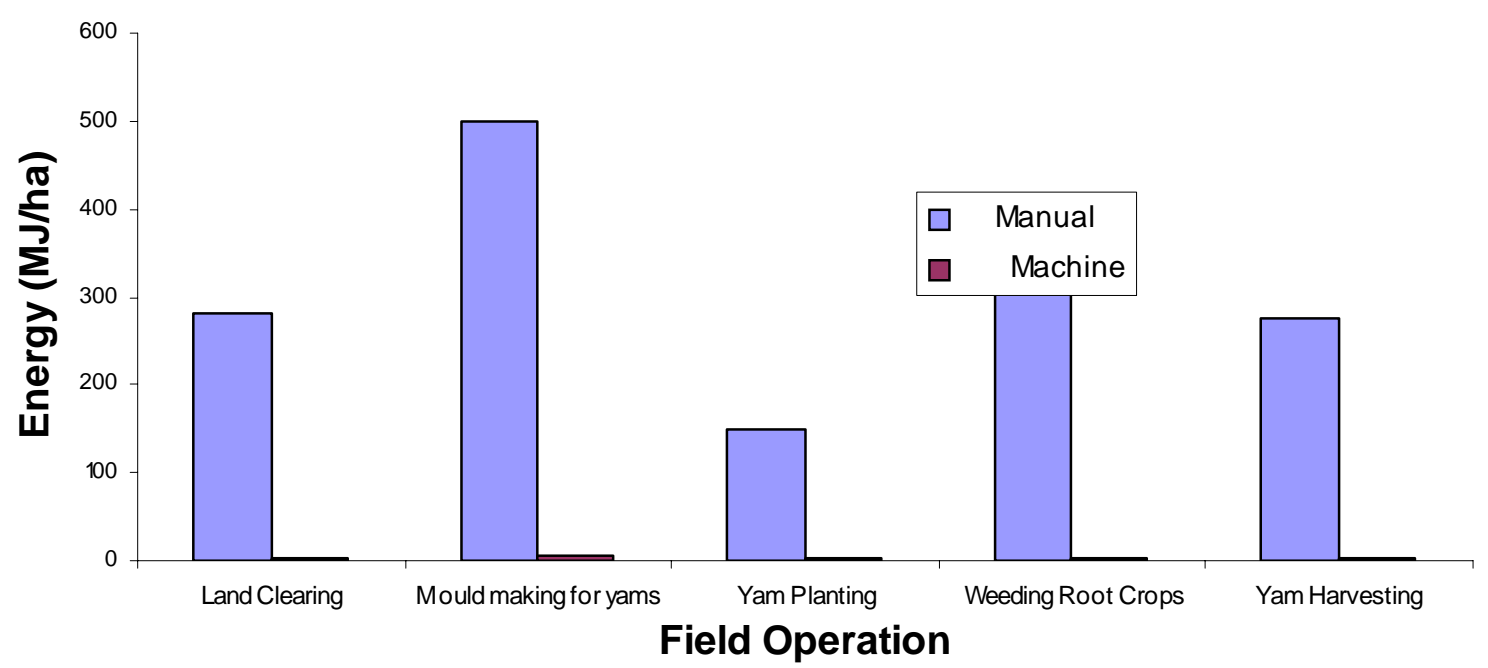

Fig.2: Energy utilization in yam cultivation in Rivers State. 


\section{REFERENCES}

1. Meshack-Hart E.T. (2000), Mechanised Agriculture for Sustainable Agricultural Development for Nigerian in the year 2010: Journal of the South-East Regional Chapter of the Nigerian Institution of Agricultural Engineers, 2000 p 39.

2. Liljedahl, J. B. Cariton, W. M., Turnquist P. K. and Smith, D. W. (1979), Tractors and their Power Units ( $3^{\text {rd }}$ ed.) John Wiley and Sons Inc., Ottawa, Canada.

3. Allison-Oguru, E. A. (1995), Overview and Evaluation of Existing Data on Agronomy / Agro-economics in the Niger Delta. Report Submitted to Eurconsult, Managing Consultants, Niger Delta Environmental Survey, Phase 1.

4. Allison-Oguru, E. A., Zuofa K, and Berepubo N. A. (1999), "Agriculture" in Alagoa, E.J. (ed). Land and People of Bayelsa State: Central Niger Delta. Port Harcourt, Onyoma Research Publication. p 283-300.

5. Odigboh E. U. (1991) "Continuing Controversies on Tillage Mechanization in Nigeria, J. Agric. Science and Technology p 41-49.

6. Kepner, R. A. Bainer, R and Barger, E. L. (1978), Principles of Farm Machinery (3 ${ }^{\text {rd }}$ edition) AVI Publishing Company Inc. Connecticut, USA.

7. Anazodo, U. G. N, Abinbola, T. O. and Dairo, J. A. (1986) "Agricultural Machinery Inventory: Type and Condition in Nigeria $(1975 \rightarrow 85)$ " Federal Department of Agriculture, Nigeria.

8. Ojah, T. P., and Michael,A. M. (1988), Principles of Agricultural Engineering, Vol. 1 Jain Brothers Publishing Co., New Delhi. p 623.

9. Culpin, C. (1975), Profitable Farm-Mechanization, Granada Publishing Co., London, p 7

10. Stout, B.A, Myers C.A., Hurand A. and Faidley L.W., (1979): Energy for World Agriculture, FAO, Agricultural Series No. 7, Rome.

11. Leach, G. (1976), Energy and Food Production. IPC Science and Technology Press, Guildford, England.

12. Igbeka J.C, (2002) "Agricultural Engineering and Society" Nigerian Institution of Agricultural Engineers Quarterly (3): 3-11. 